\title{
Adsorption of lead (II) ions by activated carbons prepared from marine green algae: equilibrium and kinetics studies
}

\author{
R. P. Suresh Jeyakumar • V. Chandrasekaran
}

Received: 24 November 2012/ Accepted: 3 November 2013/Published online: 15 March 2014

(C) The Author(s) 2014. This article is published with open access at Springerlink.com

\begin{abstract}
Background Adsorption of lead(II) ions onto activated carbons prepared from the marine green Ulva fasciata sp. (CCUC, SSUC and SCUC) and commercially activated carbon (CAC) was investigated with the variation in the parameters of $\mathrm{pH}$, contact time, lead(II) ions concentration and the adsorbent dose. The Langmuir, Freundlich and Temkin models have been applied.

Results Results showed that the adsorption process was better described by the Langmuir model. Adsorption kinetics data obtained for the metal ions sorption were investigated using reversible first order, pseudo-first order, pseudo-second order and intraparticle diffusion model. The maximum adsorption capacities $\left(\mathrm{Q}_{0}\right)$ were $22.93 \mathrm{mg} / \mathrm{g}$ for CCUC, $24.15 \mathrm{mg} / \mathrm{g}$ for SSUC, $23.47 \mathrm{mg} / \mathrm{g}$ for SSUC and $15.62 \mathrm{mg} / \mathrm{g}$ for CAC.

Conclusions It was found that the kinetics data fitted well into the pseudo second-order kinetics and SSUC is a superior adsorbent for the removal of $\mathrm{Pb}$ (II) ions from aqueous solution.
\end{abstract}

Keywords Green algae - Adsorption - Contact time . Temkin · Pseudo-first-order

\footnotetext{
R. P. S. Jeyakumar $(\bowtie)$

Department of Chemistry, Karpagam University,

Coimbatore 641021, India

e-mail: rpsjoseph3@yahoo.co.in

V. Chandrasekaran

Department of Chemistry, Govt. Arts College (Autonomous),

Salem 636 007, India

e-mail: chandru-v-m@yahoo.co.in
}

\section{Background}

The presence of heavy metals in the aquatic environmental has been a big deal to scientists and engineers due to their increased discharge, toxic nature, and other adverse effects on receiving waters $[1,2]$. Lead is widely used in many important industrial applications, such as storage battery, manufacturing, printing pigments, fuels, photographic materials, and explosive manufacturing [3]. Lead exposure causes weakness in fingers, wrists and ankles. The effects of lead toxicity are very wide ranging and include impaired blood synthesis, hypertension, severe stomach-ache, brain, kidney damage and even can cause miscarriage in pregnant women [4]. The permissible level for lead in drinking water is $0.05 \mathrm{mg} \mathrm{L}^{-1}$ according to the US Environmental Protection Agency (EPA). Therefore, a very low concentration of lead in water is very toxic [5].

The removal of such a heavy metal from contaminated water bodies has been attempted by several scientists employing a wide variety of techniques including chemical precipitation, ion-exchange, electro flotation, membrane filtration, reverse osmosis, etc. All these methods are generally expensive. For this reason, there is a need for developing economic and eco-friendly methods for waste minimization and fine-tuning of the wastewater [6]. The most popular of these technologies is activated carbon adsorption and widely used, but it is expensive. Therefore, there is a growing interest in using low-cost, easily available materials for the adsorption of metal ions. A low-cost adsorbent is defined as one which is abundant in nature, or is a by-product or waste material from another industry. Many algae, yeasts, bacteria and other fungi are known to be capable of concentrating metal species from dilute aqueous solutions and accumulating them within their cell structure [7]. Recently, green algae are attractive as they 
are ubiquitous in natural environment, have large surface area-to-volume ratio and high binding affinity to pollutants [8]. Ulva fasciata sp. algal cell walls are porous and allow the free passage of molecules and ions in aqueous solutions. The constituents of the cell wall provide an array of ligands with different functional groups capable of binding various heavy metals [9].

The objective of this work is to study the adsorption of lead (II) ions from aqueous solutions onto activated carbons from marine green $U$. fasciata and commercially activated carbon (CAC). The effects of $\mathrm{pH}$, contact time, initial lead (II) ion concentration and adsorbent dose were examined. The adsorption isotherm, kinetic and thermodynamic parameters were deduced from the adsorption measurements.

\section{Methods}

Preparation of adsorbent

The green marine algae $U$. fasciata in the present study were collected from the coastal area of Kanyakumari district, Tamil Nadu, India. The collected algae were washed with tap water and further by deionized water several times to remove impurities. The washing process was continued till the removal of all dirt. The washed algae were then completely dried in sun light for 7 days.

\section{Calcium chloride-treated $U$. fasciata carbon (CCUC)}

The dried algae $U$. fasciata to be carbonized is impregnated with solution of chloride salts such as calcium chloride for $24 \mathrm{~h}$. Accordingly, sufficient quantities were soaked well with $10 \%$ chloride solution of $5 \mathrm{~L}$ capacity, respectively, so that the solution get well adsorbed for a period of $24 \mathrm{~h}$. At the end of $24 \mathrm{~h}$ the excess solution was decanted off and air dried. Then, the materials were placed in muffle furnace carbonized at $400{ }^{\circ} \mathrm{C}$. The dried materials were powdered and activated in a muffle furnace kept at $800{ }^{\circ} \mathrm{C}$ for a period of $10 \mathrm{~min}$. After activation, the carbon was washed sufficiently with $4 \mathrm{~N} \mathrm{HCl}$ to remove the cations. Then, the materials were washed with plenty of water to remove excess acid, dried and powdered [10].

\section{Sodium carbonate treated $U$. fasciata carbon (SCUC)}

In this method the dried algae $U$. fasciata to be carbonized were soaked in $10 \%$ sodium carbonate solution for a period of $24 \mathrm{~h}$. After impregnation, the liquid portion was decanted off and the material dried. The dried mass was subjected to carbonization process at $400{ }^{\circ} \mathrm{C}$, powdered well and finally thermally activated at $800{ }^{\circ} \mathrm{C}$ for a period of $10 \mathrm{~min}[10]$.
Sodium sulphate-treated $U$. fasciata carbon (SSUC)

In this method the dried algae $U$. fasciata to be carbonized were soaked in $10 \%$ solutions of sodium sulphate for a period of $24 \mathrm{~h}$. After impregnation, the liquid portion was decanted off and then dried. The dried mass was subjected to carbonization process at $400{ }^{\circ} \mathrm{C}$ powdered well and finally thermally activated at $800{ }^{\circ} \mathrm{C}$ for a period of $10 \mathrm{~min}$ [10]. In the present study, the powdered activated carbons (CCUC, SSUC and SCUC) of algae $U$. fasciata in the range of $150 \mu \mathrm{m}$ particle size and particle size of CAC in the range of $150 \mu \mathrm{m}$ were used as adsorbents.

Preparation of metal ion solution

A stock solution of lead (II) ions concentration 1,000 mg/L was prepared by dissolving an accurate quantity of $1.6 \mathrm{~g}$ $\mathrm{Pb}\left(\mathrm{NO}_{3}\right)_{2}$ (Merck) in deionized water. Other concentrations prepared from stock solution by dilution varied between 10 and $80 \mathrm{mg} / \mathrm{L}$ and the $\mathrm{pH}$ of the working solutions was adjusted to desired values with $0.1 \mathrm{~N} \mathrm{HCl}$ or $0.1 \mathrm{~N} \mathrm{NaOH}$. Fresh dilutions were used for each experiment.

Batch adsorption studies

Batch adsorption equilibrium experiments were conducted for the adsorption of lead on activated carbons of green algae $U$. fasciata and CAC as a function of initial $\mathrm{pH}$, initial $\mathrm{Pb}(\mathrm{II})$ concentration, adsorbent dose and contact time by adding $0.2 \mathrm{~g}$ of dried carbon to $100 \mathrm{~mL}$ of lead solution with different concentrations in 250-mL stoppered reagent bottles at a constant shaking speed $(250 \mathrm{rpm})$. All the experiments were carried out at room temperature $\left(28 \pm 2{ }^{\circ} \mathrm{C}\right)$. For studying the influence of $\mathrm{pH}$ on the adsorption of $\mathrm{Pb}(\mathrm{II})$, the experiments were conducted at various initial metal solution $\mathrm{pH}$ values of $1-10$. The $\mathrm{pH}$ of each solution was adjusted to different values with either $0.1 \mathrm{~N} \mathrm{NaOH}$ or $0.1 \mathrm{~N} \mathrm{HCl}$. The concentrations of $\mathrm{Pb}(\mathrm{II})$ ions in solution before and after adsorption were determined using atomic adsorption spectrophotometer (Model Elico-SL 163, India) by monitoring the absorbance for the metal ion used. All adsorption experiments were carried out in triplicates to check the reproducibility of results. The equilibrium and kinetics data were obtained from batch experiments.

During the adsorption, a rapid equilibrium established between adsorbed metal ions on the active cites of adsorbent $\left(q_{\mathrm{e}}\right)$ and unabsorbed metal ion in the solution. The amount of adsorption at equilibrium $\left(q_{\mathrm{e}}\right)(\mathrm{mg} / \mathrm{g})$ and the percentage adsorption (\%) were computed as follows:

$q_{\mathrm{e}}=\frac{\left(C_{0}-C_{\mathrm{e}}\right) V}{X}$ 
Percentage adsorption $(\%)=\frac{\left(C_{0}-C_{\mathrm{e}}\right)}{C_{0}} \times 100$

where $C_{0}$ and $C_{\mathrm{e}}$ represented the initial and equilibrium concentrations $(\mathrm{mg} / \mathrm{L}), V$ is the volume of solution and $X$ the weight of adsorbent $(\mathrm{g})$.

\section{Results and discussion}

Effect of $\mathrm{pH}$ on $\mathrm{Pb}(\mathrm{II})$ adsorption

The $\mathrm{pH}$ of aqueous solution is an important factor and influences the metal speciation in aqueous solution as well as the surface properties of adsorbent and therefore can affect the extent of adsorption [11]. Thus, the adsorption behaviour of $\mathrm{Pb}(\mathrm{II})$ on the surface of activated carbons prepared from $U$. fasciata (CCUC, SSUC and SCUC) and commercially available activated carbon (CAC) has been investigated over a $\mathrm{pH}$ range of $1.0-10.0$ at room temperature with $100 \mathrm{~mL}$ of $\mathrm{Pb}(\mathrm{II})$ ion concentration $20 \mathrm{mg} / \mathrm{L}$ containing $0.2 \mathrm{~g}$ activated carbon and contact time $2 \mathrm{~h}$. The results are shown in Fig. 1, from the graph it is observed that the adsorption of $\mathrm{Pb}$ (II) varies with $\mathrm{pH}$ and hence $\mathrm{Pb}$ (II) adsorption on CCUC, SSUC, SCUC and CAC is highly $\mathrm{pH}$ dependent. The percentage of $\mathrm{Pb}(\mathrm{II})$ adsorption on CCUC, SSUC, SCUC and CAC increased with increasing $\mathrm{pH}$ and reached a plateau value at around $\mathrm{pH}$ range 4. Around $\mathrm{pH} 4$, the surface of activated carbon is negative and there is a strong electrostatic attraction between surface groups and $\mathrm{Pb}(\mathrm{II})$ species. As a result, at $\mathrm{pH} 4$ the adsorption of $\mathrm{Pb}$ (II) is high. Below and above of this $\mathrm{pH}$ value 4 the adsorption process was decreased. At highly acidic $\mathrm{pH}$, the overall surface charge on the active sites became positive and metal cations and protons compete for binding sites on cell wall, which results in lower

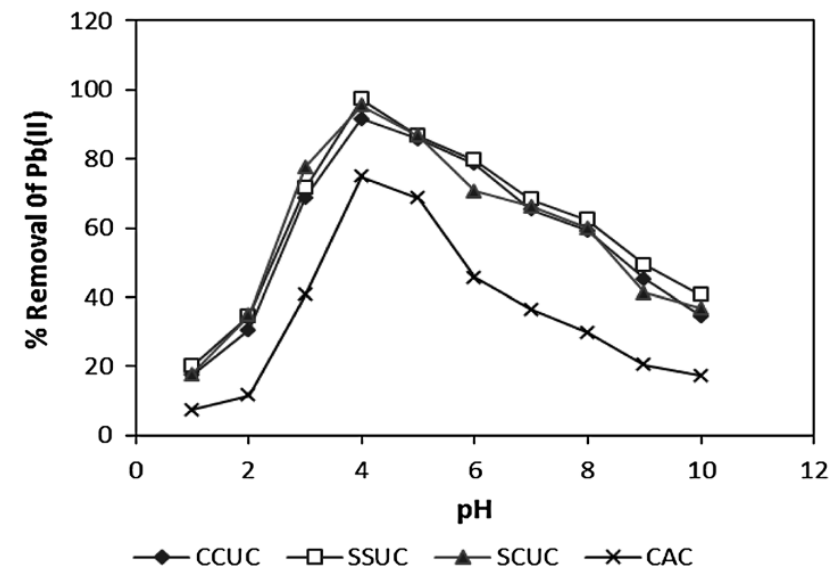

Fig. 1 Effect of $\mathrm{pH}$ on the $\mathrm{Pb}$ (II) removal (initial $\mathrm{Pb}$ (II) concentration $20 \mathrm{mg} / \mathrm{L}$, adsorbent dose $0.2 \mathrm{~g} / 100 \mathrm{~mL}$, contact time $2 \mathrm{~h}$ )

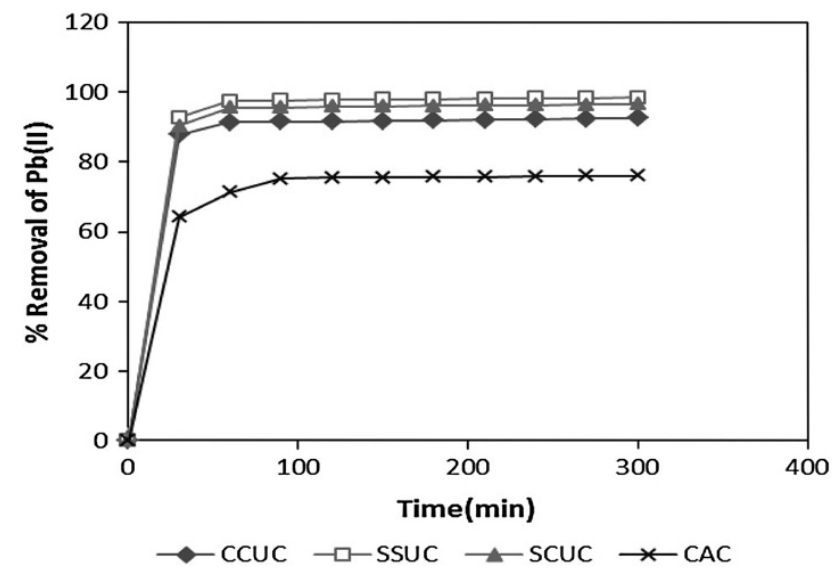

Fig. 2 Effect of contact time on the $\mathrm{Pb}$ (II) removal ( $\mathrm{pH} 4$ for CCUC, SSUC, SCUC and CAC; initial $\mathrm{Pb}(\mathrm{II})$ concentration $20 \mathrm{mg} / \mathrm{L}$, adsorbent dose $0.2 \mathrm{~g} / 100 \mathrm{~mL}$ )

uptake of metal [12]. As pH increases, more ligands such as amino, phosphate and carboxyl groups would be exposed and carry negative charges with subsequent attraction of metal ions $[13,14]$. The maximum adsorption for CCUC was found to $91.54 .62 \%$, for SSUC it was about $97.24 \%$, for SCUC was found to $95.37 \%$ and attaining maximum value of $74.87 \%$, respectively, at $\mathrm{pH} 4$. Hence, further adsorption experiments were carried out an optimum $\mathrm{pH} 4$ for CCUC, SCUC, SSUC and CAC.

\section{Effect of contact time}

Effect of contact time on the adsorbed amount of $\mathrm{Pb}$ (II) by CCUC, SSUC, SCUC and CAC was studied in the range of 30-300 min. The experiments were carried out using $100 \mathrm{~mL}$ of $\mathrm{Pb}$ (II) concentration $20 \mathrm{mg} / \mathrm{L}$ containing $0.2 \mathrm{~g}$ activated carbon at $\mathrm{pH} 4$ for CCUC, SCUC, SSUC and $\mathrm{CAC}$ with agitation speed $250 \mathrm{rpm}$ at room temperature. The results are shown in Fig. 2 and it is evident from the figure that the rate of adsorption of $\mathrm{Pb}$ (II) by CCUC, SSUC, SCUC and CAC was rapid and more than $90 \%$ $\mathrm{Pb}$ (II) ions were adsorbed within $30 \mathrm{~min}$, thereafter adsorption process was decreased gradually and became constant when equilibrium was reached. The equilibrium times for activated carbons made from U. fasciata and CAC were 60 and $90 \mathrm{~min}$, respectively. After it reached the equilibrium, there were no significance changes in lead concentration in the solution. However, as can be seen, the rate of adsorption of $\mathrm{Pb}$ (II) ions on CCUC, SSUC and SCUC surface was faster than CAC. From the results, it has been observed that $60 \mathrm{~min}$ time was sufficient for attaining the equilibrium for activated carbons of $U$. fasciata, the removal of $91.24 \% \mathrm{~Pb}$ (II) by CCUC, $97.34 \% \mathrm{~Pb}$ (II) by SSUC and $95.47 \% \mathrm{~Pb}$ (II) by SCUC. However, $75.19 \%$ of $\mathrm{Pb}$ (II) was removed by $\mathrm{CAC}$ in a period of $90 \mathrm{~min}$. 


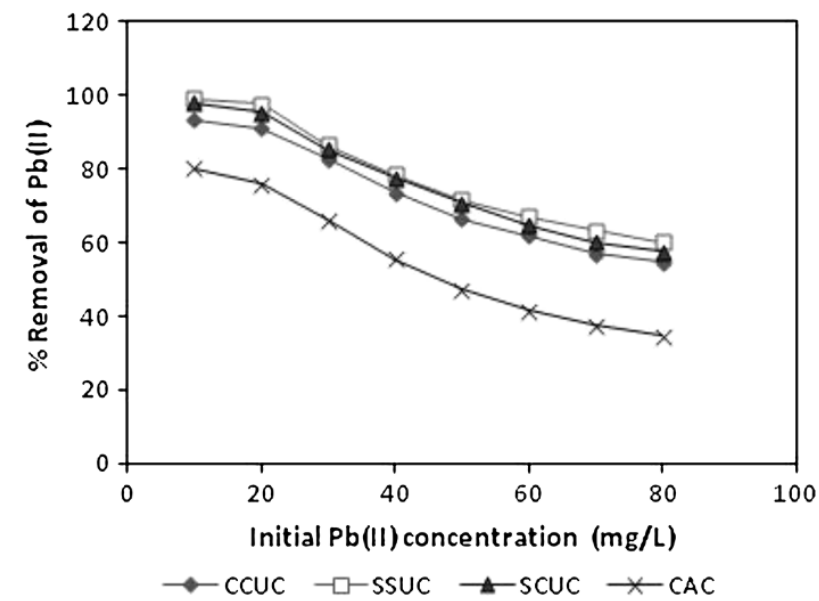

Fig. 3 Effect of initial $\mathrm{Pb}(\mathrm{II})$ concentration on the $\mathrm{Pb}$ (II) removal $(\mathrm{pH} 4$ for CCUC, SSUC, SCUC and CAC; adsorbent dose $0.2 \mathrm{~g} / 100 \mathrm{~mL}$ and contact time $2 \mathrm{~h}$ )

\section{Initial $\mathrm{Pb}(\mathrm{II})$ concentration}

The dependence of the adsorption process of lead adsorption from different initial concentrations $\left(10-80 \mathrm{mg} \mathrm{L}^{-1}\right)$ by the adsorbents is shown in Fig. 3. The experiments were carried out using $100 \mathrm{~mL}$ of $\mathrm{Pb}(\mathrm{II})$ concentrations varying from 10 to $80 \mathrm{mg} / \mathrm{L}$ at $\mathrm{pH} 4$ for CCUC, SSUC, SCUC and $\mathrm{CAC}$, an amount of $0.2 \mathrm{~g} / 100 \mathrm{~mL}$ of adsorbent was used for each adsorption experiment and contact time $2 \mathrm{~h}$. Analysis of percentage adsorption versus initial varying concentration of $\mathrm{Pb}$ (II) ions showed that the percentage adsorption decreased with increase in initial concentration of the adsorbate, but the uptake capacity increased with increase in initial concentration. At lower concentrations of lead ions, the number of lead ions which are available in the solution is less as compared to the available sites on the adsorbent. However, at higher concentrations the available sites for adsorption become fewer and the percentage removal of lead ions depends on the initial concentration. The maximum removal of $\mathrm{Pb}(\mathrm{II})$ was achieved at $10 \mathrm{mg} / \mathrm{L}$ of lead solution on CCUC, SSUC, SCUC and CAC were $93.45,99.24,97.84$ and $80.25 \%$, respectively.

\section{Effect of adsorbent dose}

To find out the effect of adsorbent dose for the adsorption of $\mathrm{Pb}$ (II) from aqueous solution, adsorption studies were carried out by varying the amount of adsorbents while keeping $\mathrm{pH} 4$ for both activated carbons of $U$. fasciata and CAC, initial metal concentration $(20 \mathrm{mg} / \mathrm{L})$, shaking speed $250 \mathrm{rpm}$ and at room temperature. The percentage of adsorption increases for an increase in adsorbent dose and remains constant as shown in Fig. 4. Higher percentage of

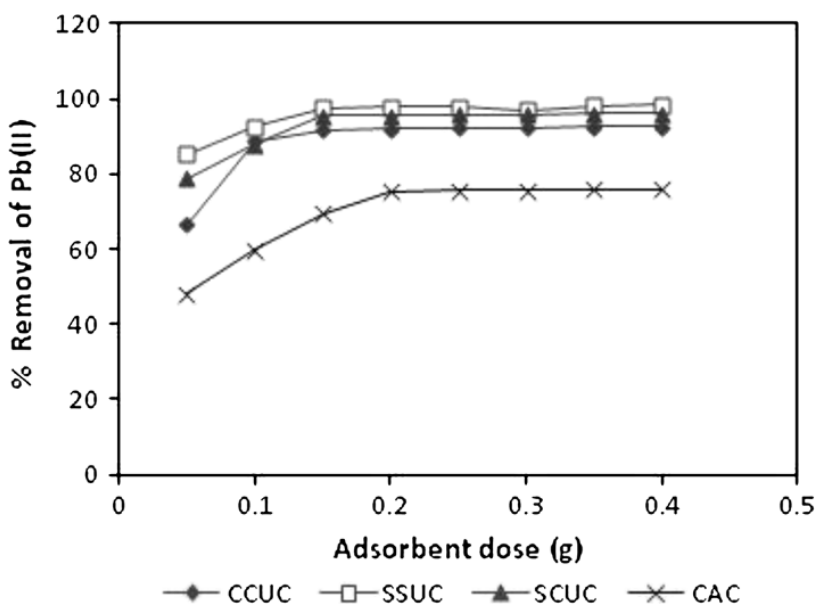

Fig. 4 Effect of adsorbent dose on the $\mathrm{Pb}$ (II) removal ( $\mathrm{pH} 4$ for CCUC, SSUC, SCUC and CAC; contact time $2 \mathrm{~h}$, initial $\mathrm{Pb}$ (II) concentration $20 \mathrm{mg} / \mathrm{L}$ )

adsorption with the increase of adsorbent concentration can be attributed to increase in surface area and the availability of more binding sites for adsorption. This suggests that after a certain dose of adsorbent, the maximum adsorption sets in and hence the amount of ions bound to the adsorbent and the amount of free ions remains constant even with further addition of the dose of adsorbent [15]. It is known that a minimum carbon dosage of $0.15 \mathrm{~g} / 100 \mathrm{~mL}$ was sufficient for the maximum removal of $91.84 \%$ lead by CCUC, $97.65 \%$ lead by SSUC and $95.48 \%$ lead by SCUC. But $0.20 \mathrm{~g} / 100 \mathrm{~mL}$ of CAC required for maximum removal of $75.42 \%$ lead. The results show that SSUC was found to be superior adsorbent than other activated carbons.

\section{Adsorption isotherms}

Adsorption isotherms express the relation between the amount of adsorbed metal ions per unit mass of biosorbent $\left(q_{\mathrm{eq}}\right)$ and the metal concentration in solution $\left(C_{\mathrm{eq}}\right)$ at equilibrium. The data of sorption equilibrium in this work was tested with Langmuir, Freundlich and Temkin isotherms as expressed in Eqs. (3), (5) and (6), respectively. The experimental data on the effect of an initial concentration of metal on the carbon of the test medium were fitted to the isotherm models and all of the constants are presented in Table 1.

Langmuir adsorption isotherm

The Langmuir adsorption model is based on the assumption of surface homogeneity such as equally available adsorption sites, monolayer surface coverage, and no 
Table 1 Langmuir, Freundlich and Temkin isotherms and their constants

\begin{tabular}{lrrrr}
\hline Isotherms and constants & \multicolumn{4}{l}{ Adsorbents } \\
\cline { 2 - 5 } & CCUC & SSUC & SCUC & CAC \\
\hline Langmuir & & & & \\
$Q_{0}$ & 22.935 & 24.154 & 23.474 & 15.625 \\
$b$ & 0.238 & 0.390 & 0.350 & 0.172 \\
$R^{2}$ & 0.983 & 0.992 & 0.9825 & 0.997 \\
$R_{\mathrm{L}}$ & 0.117 & 0.076 & 0.084 & 0.156 \\
$K_{\mathrm{F}}$ & 2.272 & 2.657 & 2.516 & 2.385 \\
Freundlich & & & & \\
$\frac{1}{n}$ & 0.353 & 0.238 & 0.284 & 0.347 \\
$R^{2}$ & 0.965 & 0.973 & 0.981 & 0.942 \\
Temkin & & & & \\
$K_{\mathrm{T}}$ & 1.965 & 5.626 & 3.327 & 1.537 \\
$B$ & 3.992 & 2.876 & 3.379 & 2.796 \\
$R^{2}$ & 0.982 & 0.926 & 0.968 & 0.982 \\
\hline
\end{tabular}

interaction between adsorbed species $[16,17]$. The mathematical description of this model is

$\frac{C_{\mathrm{e}}}{q_{\mathrm{e}}}=\frac{1}{Q_{0} b}+\frac{C_{\mathrm{e}}}{Q_{0}}$.

Based on the further analysis of Langmuir equation, the essential features of the Langmuir isotherm can be expressed in terms of a dimensionless constant, separation factor, or equilibrium parameter $R_{\mathrm{L}}$, which is defined by the following equation $[18,19]$

$R_{\mathrm{L}}=\frac{1}{1+b C_{0}}$,

where $C_{0}\left(\mathrm{mg} \mathrm{L}^{-1}\right)$ is the initial amount of adsorbate and $b\left(\mathrm{~L} \mathrm{mg}^{-1}\right)$ is the Langmuir constant described above. The $R_{\mathrm{L}}$ parameter is considered as a more reliable indicator of the adsorption There are four probabilities for the $R_{\mathrm{L}}$ value: (1) for favourable adsorption $0<R_{\mathrm{L}}<1$; (2) for unfavourable adsorption $R_{\mathrm{L}}>1$; (3) for linear adsorption $R_{\mathrm{L}}=1$, and (4) for irreversible adsorption $R_{\mathrm{L}}=0$.

The plot of $C_{\mathrm{e}} / q_{\mathrm{e}}$ versus $C_{\mathrm{e}}$ showed that the experimental data fitted reasonably well to the linearised equation of the Langmuir isotherm over the whole $\mathrm{Pb}$ (II) concentration range studied. The correlation coefficient $R^{2}, Q_{0}$ and $b$ were evaluated from the slope and intercept of the plot and are shown in Table 1. The maximum adsorption capacities $\left(Q_{0}\right)$ were $22.935 \mathrm{mg} / \mathrm{g}$ for CCUC, $24.154 \mathrm{mg} / \mathrm{g}$ for SSUC, $23.474 \mathrm{mg} / \mathrm{g}$ for SSUC and $15.625 \mathrm{mg} / \mathrm{g}$ for CAC. It is also known from the Table 1 that SSUC show maximum values of $Q_{0}(24.154 \mathrm{mg} / \mathrm{g})$ and $b(0.238 \mathrm{~L} / \mathrm{mg})$, respectively. Therefore, SSUC could be a better adsorbent for $\mathrm{Pb}$ (II) ions removal from aqueous solutions than CCUC, SCUC and CAC. In this study, the $R_{\mathrm{L}}$ values were found to be 0.117 for CCUC, 0.076 for SSUC, 0.0842 for SCUC and 0.156 in the case of CAC, respectively. Thus, $R_{\mathrm{L}}$ values are representing that adsorption of $\mathrm{Pb}(\mathrm{II})$ is favourable to Langmuir isotherm.

Freundlich adsorption isotherm

The Freundlich equation is the empirical relationship whereby it is assumed that the adsorption energy of binding to a site on an adsorbent depends on whether or not the adjacent sites are already occupied. One limitation of the Freundlich model is that the amount of adsorbed solute increases indefinitely with the concentration of solute in the solution. This empirical equation takes the form

$\log \frac{X}{m}=\log K_{\mathrm{F}}+\frac{1}{n} \log C_{\mathrm{e}}$

The linear plots of $\log X / m$ versus $\log C_{\mathrm{e}}$ give that the Freundlich isotherm was also representative for the $\mathrm{Pb}$ (II) adsorption by the activated carbon adsorbents. The correlation coefficient $R^{2}, K_{\mathrm{F}}$ and $1 / n$ were calculated from the slopes of the Freundlich plots and $1 / n$ values were found to be $0.353,0.238,0.284$ and 0.347 for CCUC, SSUC, SSUC and CAC, respectively. The magnitude of $K_{\mathrm{F}}$ and $1 / n$ shows easy separation of $\mathrm{Pb}(\mathrm{II})$ ion from water solution and high adsorption capacity. The value of $1 / n$, which is related to the distribution of bonded ions on the adsorbent surface, represents beneficial adsorption if it is between 0.1 and 1 . The $1 / n$ values for the carbon adsorbents are indicating that adsorption of $\mathrm{Pb}(\mathrm{II})$ is favourable.

\section{Temkin adsorption isotherm}

Another model, Temkin isotherm, was also used to fit the experimental data. Unlike the Langmuir and Freundlich equation, the Temkin isotherm takes into account the interactions between adsorbents and metal ions to be adsorbed and is based on the assumption that the free energy of sorption is a function of the surface coverage [20]. The isotherm is as follows:

$q_{\mathrm{e}}=B \ln K_{\mathrm{T}}+B \ln C_{\mathrm{e}}$

The Temkin isotherm assumes that the heat of adsorption of all the molecules in a layer decreases linearly due to adsorbent-adsorbate interactions and that adsorption is characterized by a uniform distribution of binding energies, up to some maximum binding energy [21]. A plot of $q_{\mathrm{e}}$ versus $\ln C_{\mathrm{e}}$ enables the determination of the isotherm constants $B$ and $K_{\mathrm{T}}$ from the slope and the intercept, respectively. Temkin constants are given in Table 1 . The correlation factors show that the Langmuir model approximation to the experimental results is better than Freundlich and Temkin model. Since the value of $R^{2}$ values nearer to 
one, indicating that the respective Langmuir and Temkin isotherm models are better fits for the experimental data.

\section{Kinetics of adsorption}

Kinetics analysis is required to get an insight of the rate of adsorption and the rate-limiting step of the transport mechanism, which are primarily used in the modelling, and design of the process. The Lagergren's pseudo-first-order, first-order reversible and pseudo-second-order model were performed to the experimental data to clarify the adsorption kinetics of $\mathrm{Pb}$ (II) ions onto activated carbons of $U$. fasciata and $\mathrm{CAC}$.

Pseudo-first-order kinetic model

The experimental data were fitted with the linear form of the pseudo-first-order rate equation by the Lagergren [22] is given as

$\log \left(q_{\mathrm{e}}-q_{t}\right)=\log q_{\mathrm{e}}-\frac{k_{1}}{2.303} t$

where $q_{\mathrm{e}}$ and $q_{t}$ are the amounts of metal adsorbed $\left(\mathrm{mg} \mathrm{g}^{-1}\right)$ at equilibrium and at time $t(\min ), k_{1}\left(\mathrm{~min}^{-1}\right)$ is the rate constant of pseudo-first-order adsorption rate. The linear plots of $\log \left(q_{\mathrm{e}}-q_{t}\right)$ versus ' $t$ ' drawn for the pseudo-first-order model is shown in Fig. 5. The rate constant $k_{1}$ can be obtained from the plot of experimental data. The plot for first-order rate equation (Eq. 6) was made at different adsorption parameters. The rate constant along with the statistical parameters such as coefficient of determination and the $R^{2}$ values from the pseudo-first-order kinetic model are given in Table 2. From the table it is observed that there is hardly any change in the value of rate constant at various adsorption parameters.

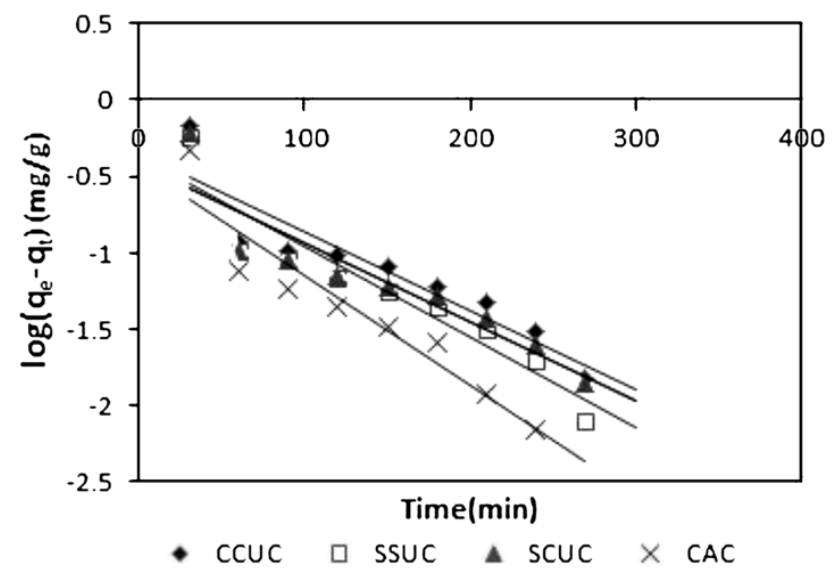

Fig. 5 Pseudo-first-order kinetics of $\mathrm{Pb}$ (II) onto activated carbons (CCUC, SSUC, SCUC) from U. fasciata and CAC
First-order reversible reaction model

The sorption of metal ion from liquid phase to solid may be considered as reversible reaction with an equilibrium state between two phases [23].

$\ln \left(1-U_{t}\right)=-\left(k_{1}+k_{2}\right)$

$U_{t}=\frac{C_{\mathrm{A} 0}-C_{\mathrm{A}}}{C_{\mathrm{A} 0}-C_{\mathrm{Ae}}}$,

where $U(t)$ is called the fractional attainment of equilibrium and is given by ' $C_{\mathrm{Ae}}$ ' and ' $C_{\mathrm{Be}}$ ' are the equilibrium concentrations of adsorbate and adsorbent, respectively. The plot of $\ln \left(1-U_{t}\right)$ against ' $\mathrm{t}$ ' for the first-order reversible rate as shown in Fig. 6 was drawn for $\mathrm{Pb}(\mathrm{II})$ adsorption on activated carbons of $U$. fasciata and CAC. The values of the first-order reversible kinetic parameters such as ' $k$ ' ' $k_{1}$ ' and ' $k_{2}$ ' were calculated using Eqs. (7) and (8) are given in Table 2.

The pseudo-second-order kinetic model

Experimental data were also tested by the pseudo-secondorder kinetic model which is given in the following form [24]:

$\frac{t}{q_{t}}=\frac{1}{k_{2} q_{\mathrm{e}}^{2}}+\frac{t}{q_{\mathrm{e}}}$,

where $k_{2}(\mathrm{~g} / \mathrm{mg} \mathrm{min})$ is the rate constant of the secondorder equation, $q_{t}(\mathrm{mg} / \mathrm{g})$ is the amount of adsorption time $t$ (min) and $q_{\mathrm{e}}$ is the amount of adsorption equilibrium (mg/g). The values of $k_{2}$ and $R^{2}$ were calculated from the plots between $t / q_{t}$ vs. $t$, which is represented in Fig. 7. The values of rate constants along with the statistical parameters are listed in following Table 2. From Table 2, it can be seen that the linear correlation $R^{2}$ of pseudo-second-order kinetic model for $\mathrm{Pb}(\mathrm{II})$ are high. However, indicated the first-order reversible and pseudo-first-order kinetic models were poor fit for $\mathrm{Pb}$ (II) adsorption. It can also be found from Table 2 that $q_{\mathrm{e}}$ values for the pseudo-second-order kinetic model are all very high. These suggested that the adsorption processes of activated carbons of $U$. fasciata and $\mathrm{CAC}$ for $\mathrm{Pb}$ (II) can be well described by the pseudosecond-order kinetic model rather than the pseudo-firstorder and first-order reversible kinetic models.

Intra-particle diffusion model

Due to porous nature of the adsorbent used in this study, pore diffusion is also expected in addition to surface adsorption. The contact time variation experiments were used to study the rate-determining step in the adsorption process. Intra-particle diffusion model used here refers to 
Table 2 Kinetics constants and their correlation coefficients

\begin{tabular}{lllll}
\hline Kinetics and constants & \multicolumn{2}{l}{ Adsorbents } & & \\
\cline { 2 - 5 } & CCUC & SSUC & SCUC & CAC \\
\hline Pseudo-first-order & & & & \\
$K_{1}$ & $11.725 \times 10^{-3}$ & $13.587 \times 10^{-3}$ & $11.975 \times 10^{-3}$ & $16.351 \times 10^{-3}$ \\
$q_{\mathrm{e}}$ & 0.7063 & 0.6901 & 0.6563 & 0.6462 \\
Reversible first-order & & & & \\
$R^{2}$ & 0.8546 & 0.8871 & 0.8499 & 0.8991 \\
$K$ & 0.0133 & 0.0136 & 0.0122 & 0.0195 \\
$k_{1}$ & 0.0108 & 0.0084 & 0.0093 & 0.0183 \\
$k_{2}$ & 0.0025 & 0.0052 & 0.0029 & 0.0012 \\
$R^{2}$ & 0.8523 & 0.8875 & 0.8557 & 0.90664 \\
Pseudo-second-order & & & & \\
$K_{2}$ & 0.5324 & 0.6861 & 0.6745 & 0.9999 \\
$q_{\mathrm{e}}$ & 9.2936 & 9.8814 & 9.6899 & 0.8421 \\
$R^{2}$ & 0.995 & 0.999 & 0.999 & 0.997 \\
\hline
\end{tabular}

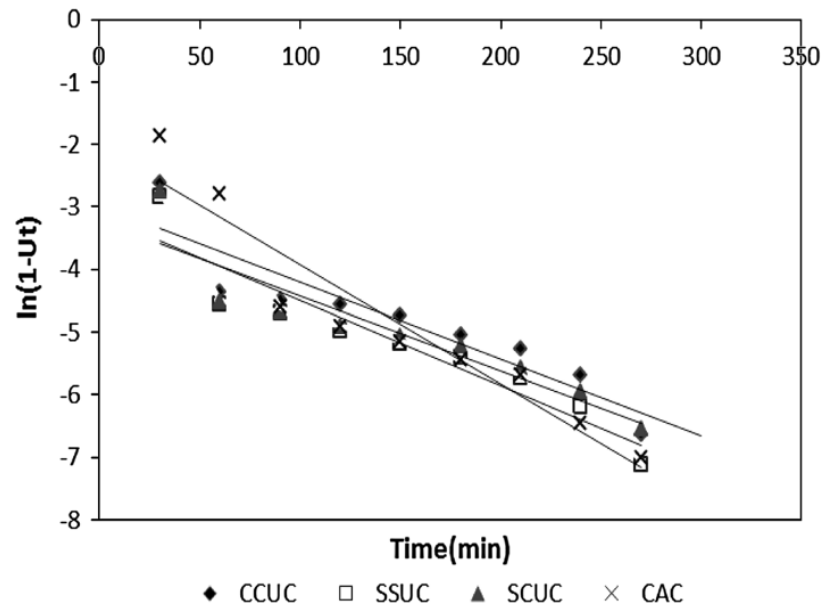

Fig. 6 First-order reversible kinetics of $\mathrm{Pb}(\mathrm{II})$ onto activated (CCUC, SSUC and SCUC) carbons from U. fasciata and CAC

the theory proposed by Weber and Morris. The initial rate of intra-particle diffusion can be obtained by linearization of the curve according to equation $[25,26]$

$q_{t}=k_{\mathrm{id}} t^{1 / 2}$,

where $q_{t}(\mathrm{mg} / \mathrm{g})$ is the amount of the metal adsorbed at time $t$ and $k_{\text {id }}$ is the intra-particle diffusion rate constant $(\mathrm{mg} /$ $\mathrm{g} \min ^{1 / 2}$ ). Figure 8 depicts that intra-particle diffusion is slow and the slope of the linear portion of the curve gives the value of $k_{\text {id. }}$.

The $k_{i d}$ values were found to be $0.0387,0.0416,0.0352$ and 0.0763 for activated carbons CCUC, SCUC, SSUC and CAC, respectively. The linear portions of the curves did not pass through the origin, hence the mechanism of lead adsorption on activated carbons (CCUC, SCUC, SSUC and CAC) is both the surface adsorption as well as intra-particle diffusion.

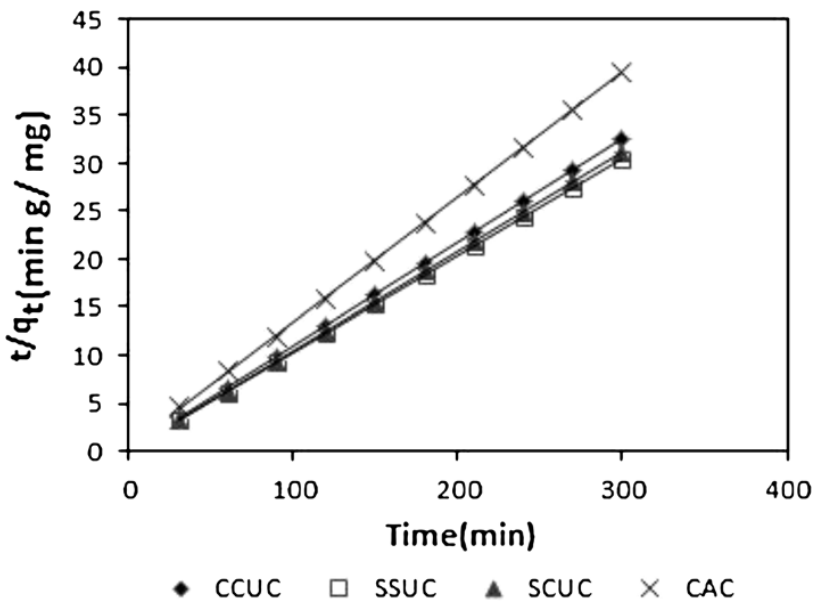

Fig. 7 Pseudo-second-order kinetics of $\mathrm{Pb}$ (II) onto activated (CCUC, SSUC and SCUC) carbons from U. fasciata and CAC

Thermodynamic studies

Temperature dependence of the adsorption process is associated with several thermodynamic parameters. In order to describe the thermodynamic behaviour of the adsorption of $\mathrm{Pb}$ (II) ions onto activated carbons, the standard Gibbs free energy is calculated by using the following equation:

$\Delta G^{0}=-R T \ln K$

where $R$ is the universal gas constant $\left(8.314 \mathrm{~J} \mathrm{~mol}^{-1} \mathrm{~K}^{-1}\right)$, $T$ is the temperature in Kelvin and $K$ is the equilibrium constant, calculated as the surface and solution metal distribution ratio $(K=1 / b)$. The negative values of $\Delta G^{0}$ $(-2.785 \mathrm{~kJ} / \mathrm{mol}$ for $\mathrm{CCUC},-2.354 \mathrm{~kJ} / \mathrm{mol}$ for $\mathrm{SSUC}$, $-2.625 \mathrm{~kJ} / \mathrm{mol}$ for SCUC and $-4.404 \mathrm{~kJ} / \mathrm{mol}$ for CAC) indicate the spontaneous nature of the adsorption process. 


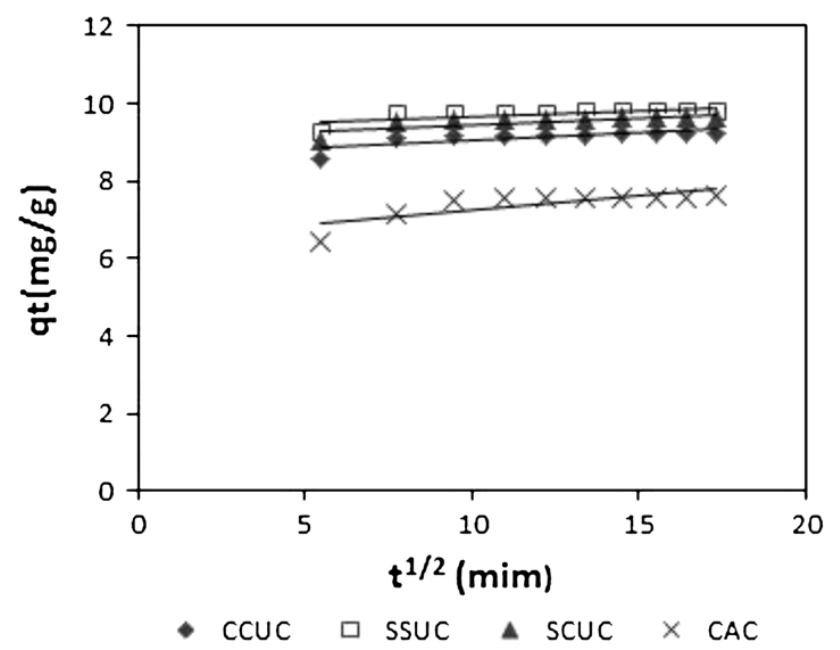

Fig. 8 Intra-particle diffusion model of $\mathrm{Pb}$ (II) onto activated (CCUC, SSUC and SCUC) carbons from U. fasciata and CAC

However, the negative value of $\Delta G^{0}$ decreases with an increase in temperature, indicating that the spontaneous nature of adsorption is inversely proportional to the temperature.

\section{Conclusions}

In this study, the use of activated carbons (CCUC, SSUC and SCUC) prepared from marine green algae U. fasciata and $\mathrm{CAC}$ were tested as adsorbents for removal of $\mathrm{Pb}(\mathrm{II})$ ions from aqueous solution. The batch study parameters, $\mathrm{pH}$ of solution, contact time, initial $\mathrm{Pb}$ (II) concentration, adsorbent dose were found to be effective on the adsorption efficiency of $\mathrm{Pb}$ (II). The Langmuir, Freundlich and Temkin isotherm models were used for the mathematical description of the adsorption of lead (II) ions onto activated carbons and the isotherm constants were evaluated from these isotherms. Results indicated that the adsorption equilibrium data fitted well the Langmuir and Temkin isotherm models. The results show that the pseudo-second-order mechanism is predominant and that chemisorption might be the ratelimiting step that controls the adsorption process. Intraparticle diffusion should also be taken into account, but it was observed that intra-particle diffusion is not a ratedetermining step. While comparing the percentage removal and adsorption capacity of activated carbons made from $U$. fasciata (CCUC, SCUC and SSUC) with CAC, the activated carbons of $U$. fasciata are superior adsorbents than CAC. This is due to more negatively charged binding sites in $U$. fasciata activated carbons than that of CAC. The study revealed that activated carbon (SSUC) from $U$. fasciata has much potential as an adsorbent for the removal of $\mathrm{Pb}(\mathrm{II})$ ions from aqueous solution.
Conflict of interest The authors declare that they have no competing interests.

Authors' contributions RPSJK carried out the experiments and analysis, VC participated ininterpretation of results and drafted the manuscript and also helped in theexperiments and analysis. Both authors have read and approved the finalmanuscript.

Open Access This article is distributed under the terms of the Creative Commons Attribution License which permits any use, distribution, and reproduction in any medium, provided the original author(s) and the source are credited.

\section{References}

1. Sekar M, Sakthi V, Rengaraj S (2004) Kinetics and equilibrium adsorption study of lead (II) onto activated carbon prepared from coconut shell. J Colloid Interf Sci 279:307-313

2. Volesky B (1990) Removal and recovery of heavy metals by biosorption. CRC Press, Boca Raton, pp 7-43

3. Jalali R, Ghafourian H, Asef Y, Davarpanah SJ, Sepehr S (2002) Removal and recovery of lead using non-living biomass of marine algae. J Hazard Mater 92:253-262

4. Toxicological profile for lead (1999) US Department of Health and Human Services, Public Health Services (Agency for Toxic Substances and Diseases Registry). Atlanta

5. Bhattacharjee S, Chakrabarty S, Maity S, Kar S, Thakur P, Bhattacharyya G (2003) Removal of lead from contaminated water bodies using sea nodule as an adsorbent. Water Res 37:3954-3966

6. Ayyappan R, Carmalin Sophia A, Swaminathan K, Sandhya S (2005) Removal of $\mathrm{Pb}$ (II) from aqueous solution using carbon derived from agricultural wastes. Process Biochem 40: 1293-1299

7. Akthar N, Sastry S, Mohan M (1995) Biosorption of silver ions by processed Aspergillus niger biomass. Biotechnol Lett 17:551-556

8. Chong AMY, Wong YS, Tam NFY (2000) Performance of different microalgal species in removing nickel and zinc from industrial wastewater. Chemosphere 41:251-257

9. Gong R, Ding YD, Liu H, Chen Q, Liu Z (2005) Lead biosorption by intact and pretreated spirulina maxima biomass. Chemosphere 58:125-130

10. Karthikeyan S, Sivakumar P, Palanisamy PN (2008) Novel activated carbons from agricultural wastes and their characterization. Electron J Chem 5:409-426

11. Sreejalekshmi KG, Krishnan KA, Anirudhan TS (2009) Adsorption of $\mathrm{Pb}(\mathrm{II})$ and $\mathrm{Pb}(\mathrm{II})$-citric acid on sawdust activated carbon: kinetic and equilibrium isotherm studies. J Hazard Mater 161:1506-1513

12. Iqbal M, Edyvean R (2004) Biosorption of lead, copper and zinc ions on loofa sponge immobilized biomass of Phanerochaete chrysosporium. Miner Eng 17:217-223

13. Onmez GCD, Aksu Z, Ozturk A, Kutsal T (1999) A comparative study on heavy metal biosorption characteristics of some algae process. Biochem 34:885-889

14. Aksu Z (2001) Equilibrium and kinetic modelling of cadmium(II) biosorption by $C$. vulgaris in a batch system: effect of temperature. Sep Purif Technol 21:285-294

15. Nomanbhay SF, Palanisamy K (2005) Removal of heavy metal from industrial wastewater using chitosan coated oil palm shell charcoal. Electron J Biotechnol 8:44-53

16. Arica MY, Bayramoglu G, Yilmaz M, Genc O, Bektas S (2004) Biosorption of $\mathrm{Hg}^{2+}, \mathrm{Cd}^{2+}$ and $\mathrm{Zn}^{2+}$ by Ca-alginate and immobilized wood-rotting fungus Funalia trogii. J Hazard Mater 109:191-199 
17. Sheng PX, Ting YP, Chen JP, Hong L (2004) Sorption of lead, copper, cadmium, zinc, and nickel by marine algal biomass: characterization of biosorptive capacity and investigation of mechanisms. J Colloid Interface Sci 27:131-141

18. Malkoc E, Nuhoglu Y (2007) Potential of tea factory waste for $\mathrm{Cr}(\mathrm{VI})$ removal from aqueous solution: thermodynamic and kinetic studies. Sep Purif Technol 54:291-298

19. Ozer A, Ozer D (2004) The adsorption of copper (II) ions on to dehydrated wheat bran (DWB): determination of the equilibrium and thermodynamic parameters. Process Biochem 39(12):2183-2191

20. Deng SB, Ting YP (2005) Fungal biomass with grafted poly (acrylic acid) for enhancement of $\mathrm{Cu}(\mathrm{II})$ and $\mathrm{Cd}(\mathrm{II})$ biosorption. Langmuir 21:5940-5948

21. Areco MM, Afonso MS (2010) Copper, zinc, cadmium and lead biosorption by Gymnogongrus torulosus. Thermodynamics and kinetics studies. Biointerfaces 81:620-628
22. Lagergren S, Svenska BK (1898) Zur theorie dersogenannten adsorption geloester stoffe Vetenskapsakad Handlingar. Band 24:1-39

23. Michelsen L, Gideon P, Pace E, Kutal L (1975) Removal of soluble $\mathrm{Hg}$ from water by complexing techniques, United States Department of Interior (U. S. D. I) Office of Water Research and Technology, Bull No 74

24. Ho YS, McKay G (1999) Pseudo-second order model for sorption processes. Process Biochem 34:451-465

25. Guibal E (1998) Metal-anion sorption by chitosan beads: equilibrium and kinetic studies. Ind Eng Chem Res 37:1454-1463

26. Weber W (1963) Kinetics of adsorption on carbon from solution Sanit. Eng Div Am Soc Civ Eng 89 (SA2:31-40) 